\title{
GEODESIGN AND SIMULATION OF TWO AUSTRALIAN COMMUNITIES 2016-2050: WHAT DOES THE FUTURE HOLD ARE THEY SUSTAINABLE OR NOT?
}

\author{
M. Herron*, D. Jones**, P. Roos***, C. Donley**** \\ *School of Architecture \& Built Environment, Deakin University \\ Geelong,Australia.jmher@deakin.edu.au \\ *School of Architecture \& Built Environment, Deakin University \\ Geelong, Australia \\ ***School of Architecture \& Built Environment, Deakin University, Geelong \& Jacobs \\ Melbourne, Australia \\ ****Donley \& Associates, Colorado Springs \\ Colorado, USA
}

\begin{abstract}
This paper demonstrates the ability of visualization and simulation techniques to aid, and simulate current and future directions in coastal planning. Two communities examined are the coastal city of Hobsons Bay on Port Phillip Bay within the Melbourne metropolitan region and the coastal rural town of Apollo Bay, in Australia, are interrogated through a progression of projections and simulated forecasts from 2014 to 2050 . The purpose is to comprehend their growth risks as it relates to their coastal edges and land use planning mechanisms in addressing these changes. The analysis uses Geographic Information Systems (GIS) associated with planning application software, and the paper offers recommendations in progressing this inquiry.
\end{abstract}

Keywords: GeoDesign, climate change, Australian communities.

Introduction. Coastal cities around the world over the past few decades have grown at an incredible rate. Integral with this growth have come major challenges relating to land use planning, social relationships, economic development, bio-diversity and the degradation of the ecological footprint. In addition, three forces are influencing the growth rate of coastal cities in Australia. These forces include: population growth (i.e. the type and quantity of human demand for land); the existing and future properties of the land (i.e. current land status or changes due to nature and human activities); and, finally technical changes of a land use planning system (i.e. zoning or the influence of other external factors).

As this development growth continues one question that arises is 'is this continued growth or development sustainable?' Ciegis (2009) described the problems of trying to identify the essential features of sustainable development that offer models of management of 'sustainable development'. With his comparison and the clarification of processes, Ciegis (2009) concludes that none of the hundreds of 'sustainable development' definitions found in the literature include all aspects of the concept and provide a perfect understanding of the concept. He concluded that the most appropriate definition that best expresses the idea of sustainable development is proposed by the World Commission on Environment and Development (World Commission onEnvironment and Development (WCED) 1987) in their Our common future report, termed the Brundtland Commission. In this report, the concept of sustainability development is based on three pillars: economic, social and environmental sustainability.

The Brundtland (World Commission onEnvironment and Development (WCED) 1987) definition, now extensively adopted by the Australia planning profession, stated sustainable development is: "...development that meets the needs of the present without compromising the ability of future generations to meet their own needs."The Brundtland definition offers a guide to better address a research problem that can be developed for sustainable current and future coastal city development in Australia. To test this hypothesis, the current and future development patterns of the Town of Apollo Bay and the City of Hobsons Bay in the state of Victoria in Australia were simulated and analysed. Three scenarios were developed for Apollo Bay and Hobsons Bay, based on the Victorian state government population and housing forecasts to 2050 .

The three scenarios included a low scenario equating to $90 \%$ of the Victorian government predicted population and housing growth forecast to 2050, a base scenario which is the actual Victorian government forecast and a high scenario which is $110 \%$ of the Victorian government population and housing forecast to 2050 (Victorian Department of Planning and Community Development 2014). The key element in the three scenarios is growth in the number of houses per 5-year period.

This paper addresses the need to efficiently plan for future urban growth involving a two-step process. Step one disaggregates demographic and social economic information. Step two combines this information with environmental, infrastructure and forecast data within land use models. As a consequence, one research question pursued is can visualization techniques portray information that is legible, easy to understand and thus more likely to be used by land use practitioners.

Test sites. To test and validate the study research statement a case study approach was used to analyse and visualize land for the future growth of Apollo Bay and Hobsons Bay. Apollo Bay, situated on the Victorian coastline $187 \mathrm{~km}$ south west of Melbourne.Apollo Bay is a small settlement with a population of 1380 and has a population density of $281.63 \mathrm{~km}^{2}$. Apollo Bay has an area of $4.9 \mathrm{~km}^{2}$ in size comprising 2348 parcels or lots of which 1156 are occupied by private dwellings. The dominant employment sectors are 'accommodation' and 'food services' that represents $28.05 \%$, 'health care' and 'social assistance' that represents $11.59 \%$, 'retail trade' represents $11.38 \%$ and 'construction' $10.57 \%$ of the workforce. 
The City of Hobsons Bay represents a coastal city situated on the north-western flank of Port Phillip Bay around $10 \mathrm{~km}$ west of central Melbourne. With a population of 89,111 people, Hobsons Bay has a current population density of $1388.22 \mathrm{~km}^{2}$. The City has an area of $64 \mathrm{~km}^{2}$ in size comprising 41,686 parcels or lots of which 35,386 are occupied by private dwellings. The dominant employment sectors are manufacturing which represent $11.3 \%$ of the workforce, healthcare at $9.4 \%$ and retail which represents $9.1 \%$ of the workforce.

Research Methodology, Software and Data. The study methodology used for the research is based upon the concept of scenario planning. This concept focuses upon the use of scenarios, including; Landscape visualization; Sustainable development evaluations; Multi-criteria analysis; Categorization of tools for sustainability analysis; and, spatial models through the use of Geographical Information Systems (GIS).

Walker (2011) observes that "for the purpose of this discussion the term scenario is defined as an alternative plan that is being considered". Walker's definition was used against three scenarios that were developed to test the research question. Three scenarios developed included:

1. A low scenario equating to $90 \%$ of the Victorian state government predicted population and housing growth forecast to 2050;

2. A base scenario that is the actual Victorian state government forecast; and,

3. A high scenario which is $110 \%$ of the Victorian state government population and housing forecast to 2050.

Growth is the key element in calculating the number of houses per five-year period. Growth underpins all of the sustainability indicators. The use of indicators is crucial because they represent a measure of comparable success of each scenario that is developed. The primary goal of scenario planning is to correctly rank scenarios by each indicator score. A build-out analysis was performed on the Apollo Bay and Hobsons Bay as part of this process. The build-out analysis depicts the residential, industrial and commercial potential of the respective communities from 2016 through 2050.

As part of this investigation, Community Viz (Walker 2011) was used. Community Viz is a planning and simulation software package. To develop economic, demographic and planning scenarios Community Vizsoftware performs four functions including: the estimation, amount and location of new development allowed in an area according to current or proposed zoning regulations; the suitability of the new development to an area; the allocation of where growth is most likely to occur over a specific time span and finally the development of a series of environmental indicators showing the impact of the new development on the landscape. A suitability analysis was performed on the respective build out results for each city with criteria drawn from the suitability analysis including: Proximity to the city centre; Sewer access; Proximity to hazardous areas; and Shoreline access.

The next analysis stage embraces an allocation procedure that involves taking the results from the build out and suitability analysis and allocated the demand for buildings across the available supply of potential building locations. Through the impact function in Community Viz, 15 indicators were developed showing the impact of development over time on the urban landscape (fig. 1).

\begin{tabular}{|c|c|c|c|}
\hline Indicator & units & Indicator & units \\
\hline $\begin{array}{l}\text { Common Impacts - Annual CO Auto } \\
\text { Emissions }\end{array}$ & lbs & $\begin{array}{c}\text { Common Impacts - Commercial } \\
\text { Jobs to Housing Ratio }\end{array}$ & $\begin{array}{l}\text { commercial jobs / } \\
\text { dwelling unit }\end{array}$ \\
\hline $\begin{array}{l}\text { Common Impacts - Annual } \mathrm{CO}^{2} \mathrm{~A} \\
\text { to Emissions }\end{array}$ & tons & $\begin{array}{l}\text { Common Impacts - Labour } \\
\text { Force }\end{array}$ & workers \\
\hline $\begin{array}{l}\text { Common Impacts - Annual Hydro- } \\
\text { carbon Auto Emissions }\end{array}$ & lbs & Common Impacts - Population & persons \\
\hline $\begin{array}{l}\text { Common Impacts }- \text { Annual NOx } \\
\text { Auto Emissions }\end{array}$ & lbs & $\begin{array}{c}\text { Common Impacts - Residential } \\
\text { Dwelling Units }\end{array}$ & dwelling units \\
\hline $\begin{array}{l}\text { Common Impacts - Commercial En- } \\
\text { ergy Use }\end{array}$ & $\begin{array}{l}\text { million BTU } \\
\text { / year }\end{array}$ & $\begin{array}{c}\text { Common Impacts - Residential } \\
\text { Energy Use }\end{array}$ & $\begin{array}{l}\text { million BTU / } \\
\text { year }\end{array}$ \\
\hline $\begin{array}{l}\text { Common Impacts }- \text { Commercial } \\
\text { Floor Area }\end{array}$ & sq. metres & $\begin{array}{c}\text { Common Impacts - Residential } \\
\text { Water Use }\end{array}$ & gallons / year \\
\hline Common Impacts - Commercial Jobs & $\begin{array}{l}\text { commercial } \\
\text { jobs }\end{array}$ & $\begin{array}{l}\text { Common Impacts - School } \\
\text { Children }\end{array}$ & school children \\
\hline
\end{tabular}

Fig. 1. Study Indicators. Source: (Walker 2011)

The Build-out, Suitability and Allocate analyses were performed on the Apollo Bay and Hobson Bay data. The suitability analysis on Apollo Bay used 7 criteria included: boreholes, coastal flooding projections from 2040 to 2100, and trees and native vegetation. The Hobsons Bay analysis used 12 criteria including: coastal flooding projections from 2040 to 2100; proximity to oil refineries, chemical plants and oil tank farms; and, trees and native vegetation.

Apollo Bay. For the period 2016 through to 2050 for Apollo Bay the number of new dwelling constructed could range from 839 to 1065 new dwellings. 
Table 1

Three Growth Scenarios for Apollo Bay 2016-2050. Source: (Victorian Department of Planning and Community

\section{Low / Base / High Scenarios}

Population Dwelling and New Dwelling Units were forecast to be:

$\begin{array}{lrrrrrrrrr}\text { Scenario1 Low } & \underline{2011} & \underline{2016} & \underline{2021} & \underline{2026} & \underline{2031} & \underline{2036} & \underline{2041} & 2046 & 2051 \\ \text { Population } & 2577 & 2602 & 2784 & 2939 & 3082 & 3113 & 3145 & 3176 & 3208 \\ \text { Houses } & 3064 & 3092 & 3285 & 3440 & 3554 & 3589 & 3678 & 3790 & 3903 \\ \text { difference } & & 28 & 221 & 376 & 490 & 525 & 614 & 726 & 839 \\ & & & & & & & & & \\ \underline{\text { Scenario 2 Medium }} & \underline{2011} & \underline{2016} & \underline{2021} & \underline{2026} & \underline{2031} & \underline{2036} & \underline{2041} & 2046 & 2051 \\ \underline{\text { Scenario }} & 2577 & 2739 & 2931 & 3094 & 3245 & 3277 & 3310 & 3343 & 3377 \\ \begin{array}{l}\text { Population } \\ \text { Houses }\end{array} & 3064 & 3255 & 3458 & 3621 & 3741 & 3778 & 3872 & 3989 & 4108 \\ \text { difference } & & 191 & 394 & 557 & 677 & 714 & 808 & 925 & 1044 \\ & & & & & & & & & \\ \text { Scenario 3 High Scenario } & \underline{2011} & \underline{2016} & \underline{2021} & \underline{2026} & \underline{2031} & \underline{2036} & \underline{2041} & 2046 & 2051 \\ \text { Population } & 2577 & 2766 & 2960 & 3125 & 3277 & 3310 & 3343 & 3376 & 3411 \\ \text { Houses } & 3064 & 3271 & 3475 & 3639 & 3760 & 3797 & 3891 & 4009 & 4129 \\ \text { difference } & & 207 & 411 & 575 & 696 & 733 & 827 & 945 & 1065\end{array}$

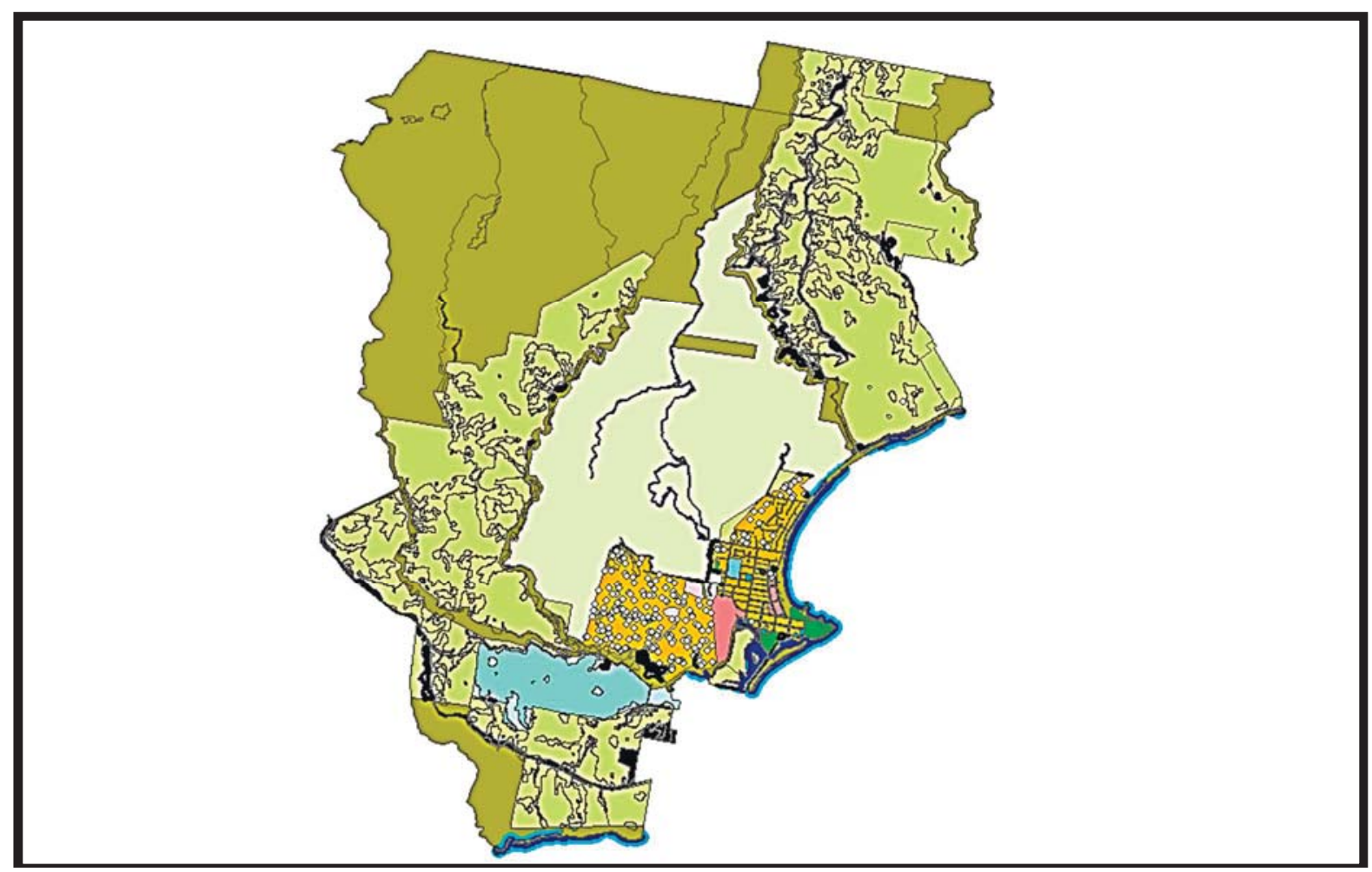

Fig. 2. Apollo Bay Development, 2016. Source: (Victorian Department of Primary Industry 2013) 


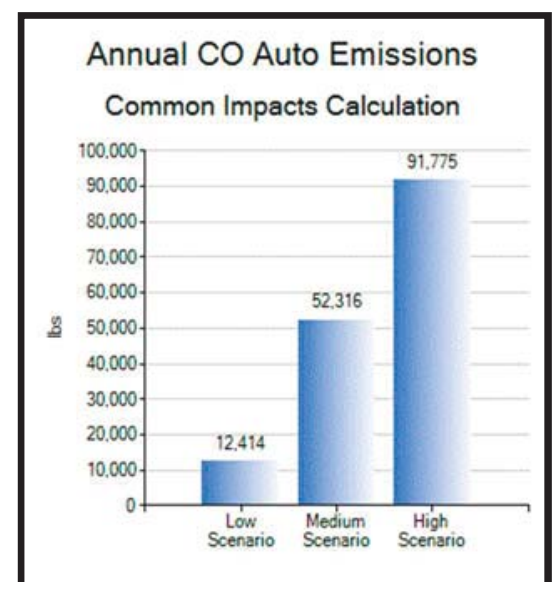

Fig. 3. 2016 CO Auto Emissions

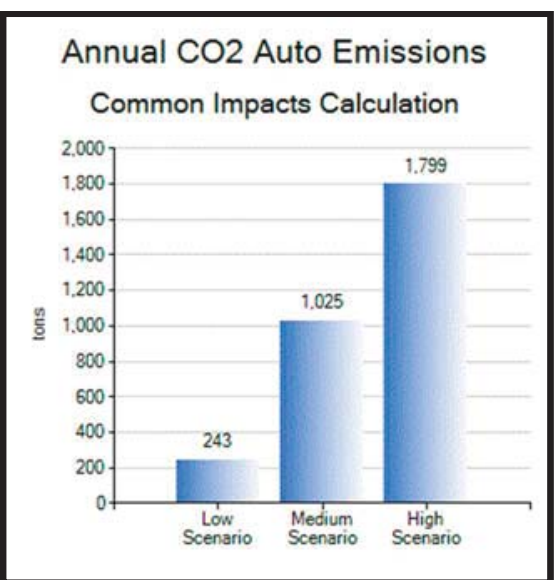

Fig. 5.2016 CO2 Auto Emissions

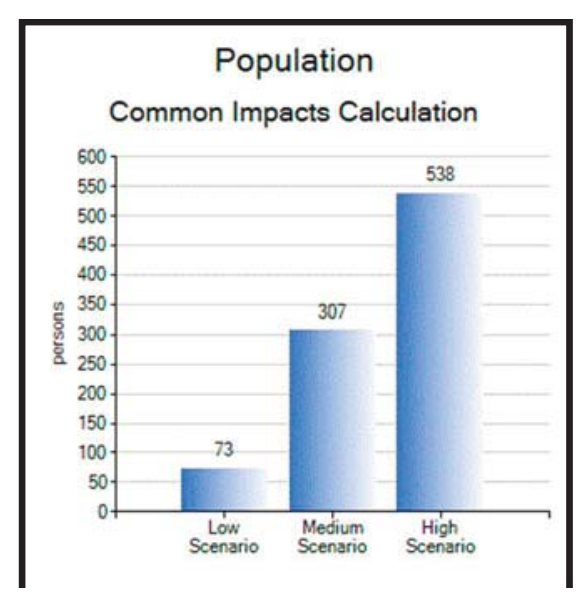

Fig. 7. 2016 Population Increase

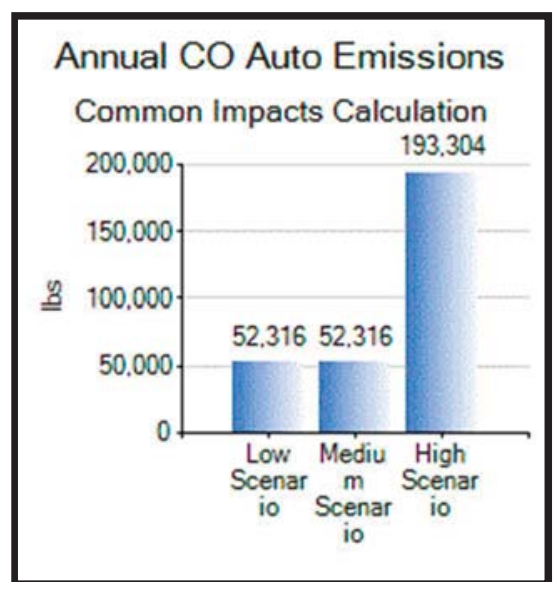

Fig. 4. 2050 CO Auto Emissions

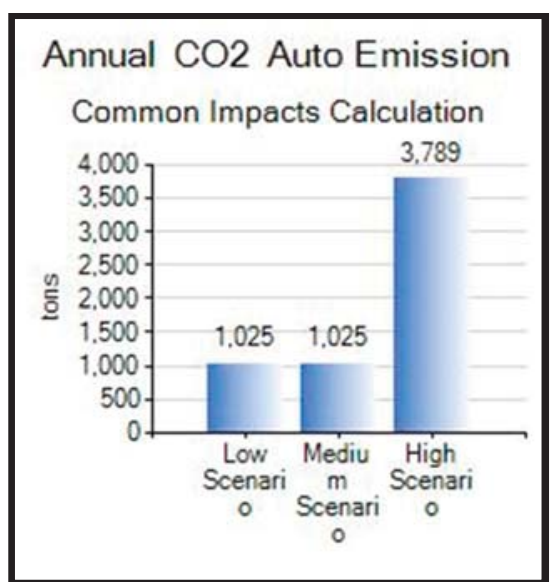

Fig. 6. 2050 CO2 Auto Emissions

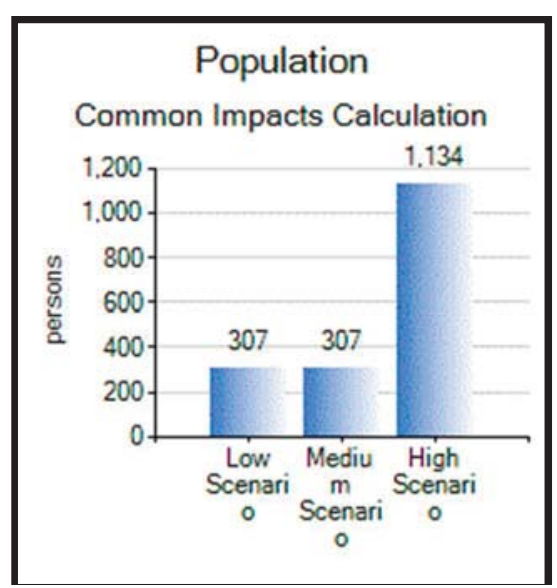

Fig. 8. 2050 Population Increase 


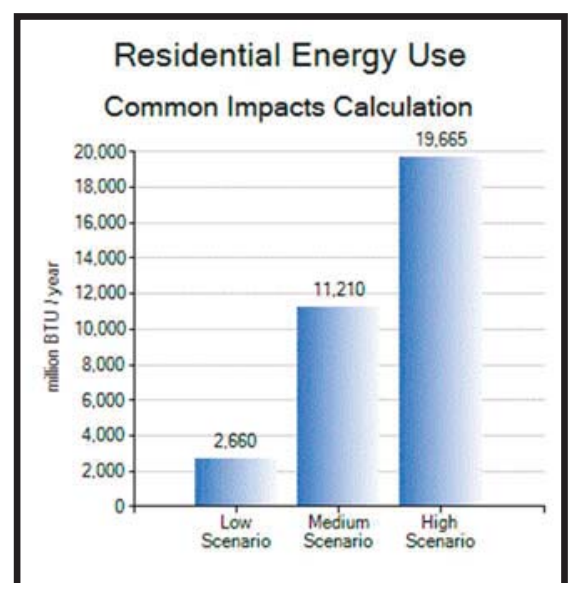

Fig. 9. 2016 Residential Energy Use

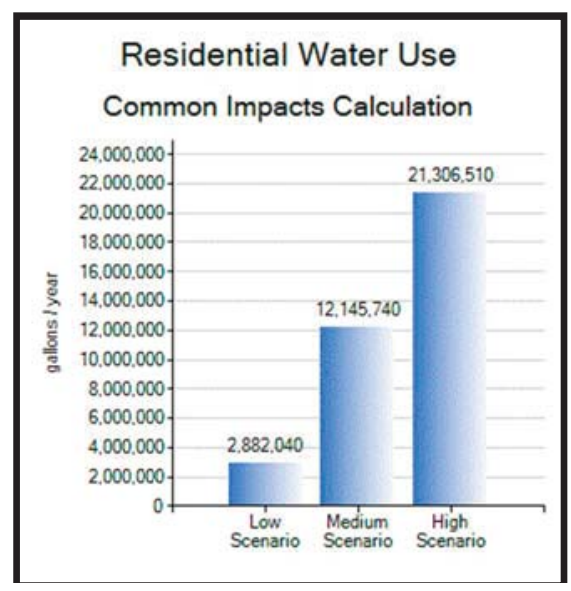

Fig. 11. 2016 Residential Water Use

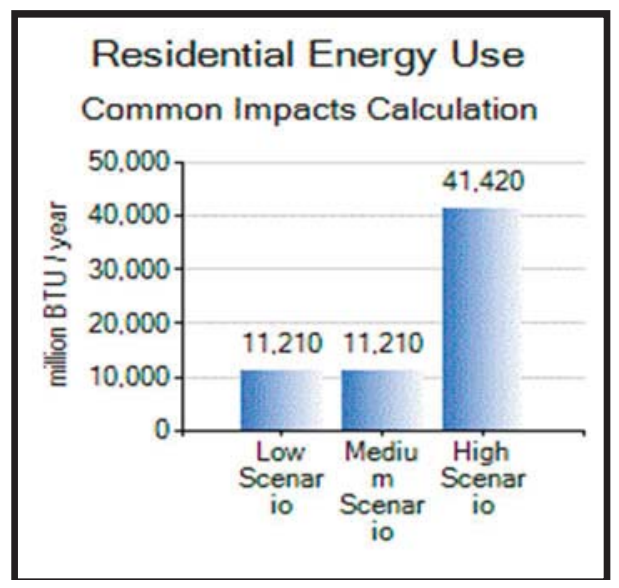

Fig. 10. 2050 Residential Energy Use

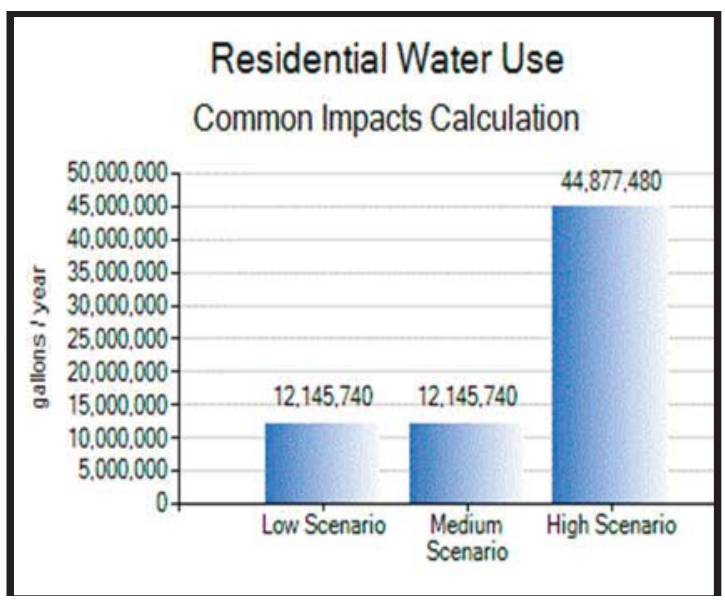

Fig. 12. 2050 Residential Water Usage Source: (Herron 2012)

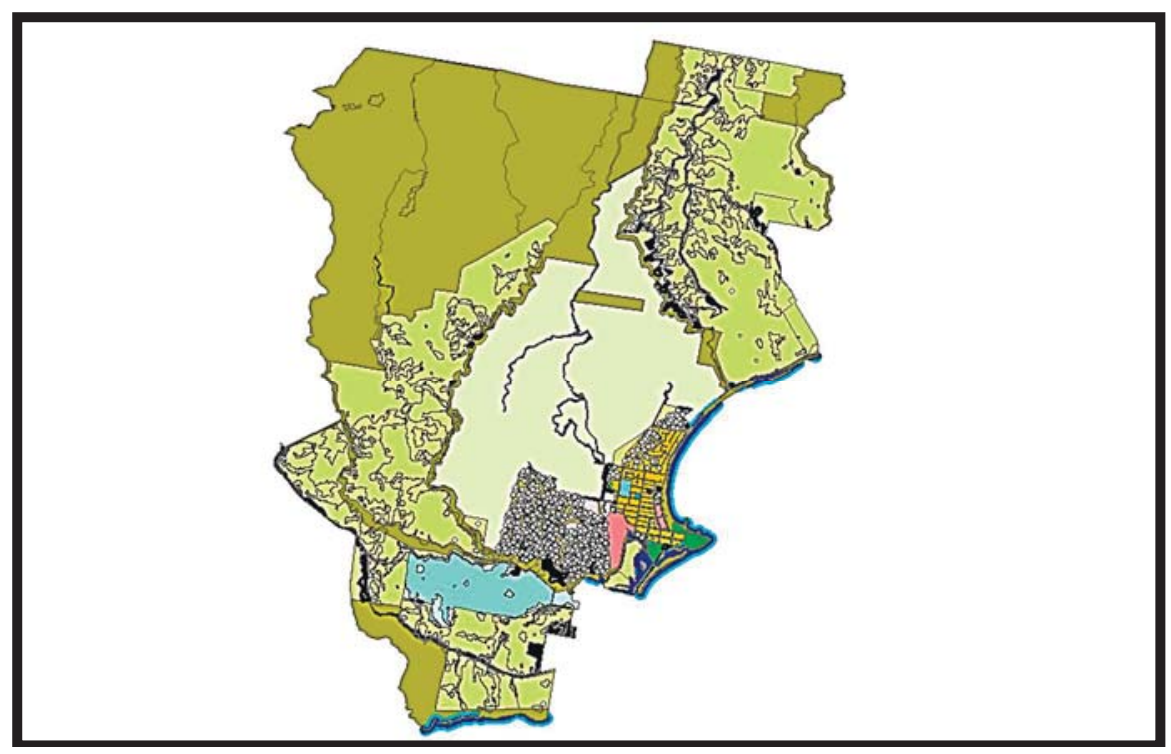

Fig. 13. Apollo Bay Development 2050. Source: (Victorian Department of Primary Industry 2013)

Apollo Bay Results.Every indicator showed a substantial increase as a consequence of increased population or development pressures. Figures 3 through 12 are samples of the simulated results for 2016 and 2050.

The research undertaken for this paper relating to the Apollo Bay has generated six discussion points which are listed below that can be summarized as: Population increases generating more emissions and greater impacts of climate change; Increased consumption of energy and water resources; Open space allowances decrease for new developments and General overall open space decreases per head of population; Urban density increases; New resi- 
dential and or commercial development will add greater stress on existing physical and or natural infrastructure and, More mixed commercial / residential developments in the metropolitan and regional centers. The detail of these 6 conclusions are detailed in table 2.

Three Growth Scenarios for Apollo Bay 2016-2050

Table 1

\begin{tabular}{|l|l|}
\hline 1 & $\begin{array}{l}\text { Population increases generating more emissions and greater Climate Change impacts. As the project } \\
\text { population increases the environmental indicators used to highlight environmental degradation increased } \\
\text { (i.e. } \mathrm{CO}, \mathrm{CO}^{2} \text {, Auto Emissions, residential water and energy consumption, etc.) The level of increase is } \\
\text { predicated on the number of cars and individuals per household. The more individuals or cars per } \\
\text { household the greater level of emission or consumption of water and energy per household. In Apollo } \\
\text { Bay there very limited possibility to reduce car numbers per household as adequate mass public } \\
\text { transport does not exist in the community. }\end{array}$ \\
\hline 2 & $\begin{array}{l}\text { Water and energy consumption will increase as the result of population growth. The vast majority of } \\
\text { electricity generated in Victoria is from the burning of brown and black coal. Increased electricity sup- } \\
\text { ply generated by renewable forms of energy may assist in reducing the impacts of climate change. }\end{array}$ \\
\hline 3 & Open space ratio will decrease with the increasing population. \\
\hline 4 & $\begin{array}{l}\text { The urban density will go up from } 281 \text { personper square km }{ }^{2} \text { to potentially over } 600 \text { persons per sq. } \\
\text { Km }\end{array}$ \\
\hline 5 & $\begin{array}{l}\text { New residential and or commercial development will put additional stress on theexisting physical infra- } \\
\text { structure }\end{array}$ \\
\hline 6 & More mixed commercial / residential development .with the adventof new planning zones in Victoria \\
\hline
\end{tabular}

Hobsons Bay. For the period 2016 to 2050 the number of new dwellings constructed could range from 12,686 to 28,746 dwelling units (tabl. 3). Fig. 14 depicts residential development in 2016 and fig. 25 shows development in 2050. Residential development is represented by yellow dots and commercial development by red dots. Three scenarios (tabl. 3) were developed from the Victorian state government population and housing forecast to 2050 .

Table 3

Three Growth Scenarios for Hobsons Bay 2016-2050. Source:(Victorian Department of Planning and Community Development 2014)

\section{Low / Base / High Scenarios}

\section{- Population Dwelling and New Dwelling Units were} forecast to be:

\begin{tabular}{|l|c|c|c|c|c|c|c|c|}
\hline & 2016 & 2021 & 2026 & 2031 & 2036 & 2041 & 2046 & 2050 \\
\hline Scenario 1 Low Population & 81996 & 84848 & 87602 & 90119 & 93,002 & 95,977 & 99,047 & 102,215 \\
\hline Total Dwelling & 33370 & 34902 & 36359 & 37739 & 39,319 & 40,965 & 42,680 & 44,467 \\
\hline New Dwelling Units & 1376 & 1432 & 1489 & 1549 & 1,611 & 1,675 & 1,742 & 1,812 \\
\hline Scenario 2 Average Population & 91,107 & 94,275 & 97,336 & 100,132 & 103,335 & 106,641 & 110,052 & 113,572 \\
\hline Total Dwelling & 37,078 & 38,780 & 40,399 & 41,932 & 43,688 & 45,517 & 47,422 & 49,408 \\
\hline New Dwelling Units & 2111 & 2577 & 2224 & 2,342 & 2,184 & 2,419 & 2,407 & 2,528 \\
\hline Scenario 3 High Population & 100,218 & 103,703 & 107,070 & 110,145 & 113,669 & 117,305 & 121,057 & 124,930 \\
\hline Total Dwelling & 40,786 & 42,658 & 44,439 & 46,125 & 48,056 & 50,068 & 52,164 & 54,348 \\
\hline New Dwelling Units & 2,753 & 2,974 & 3,211 & 3,468 & 3,746 & 4,046 & 4,369 & 4,179 \\
\hline
\end{tabular}




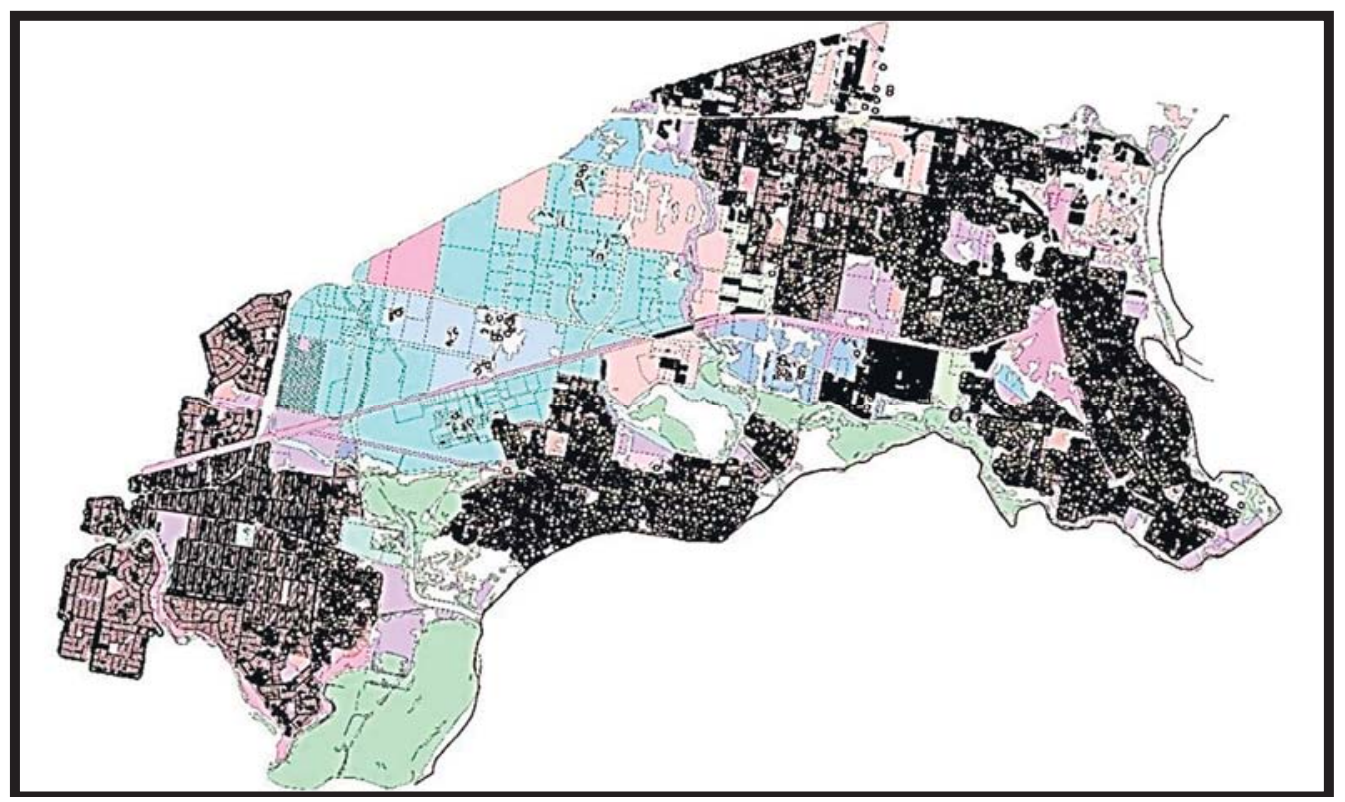

Fig. 14. City of Hobsons Bay Development 2016. Source:(Herron 2012)

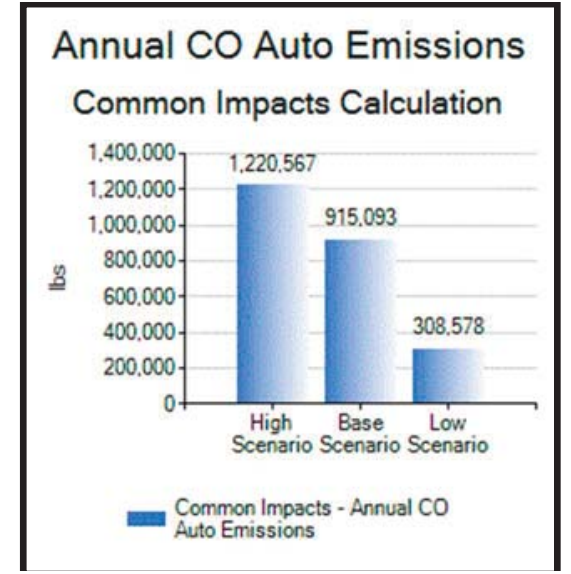

Fig.2. 2016 CO Auto Emissions

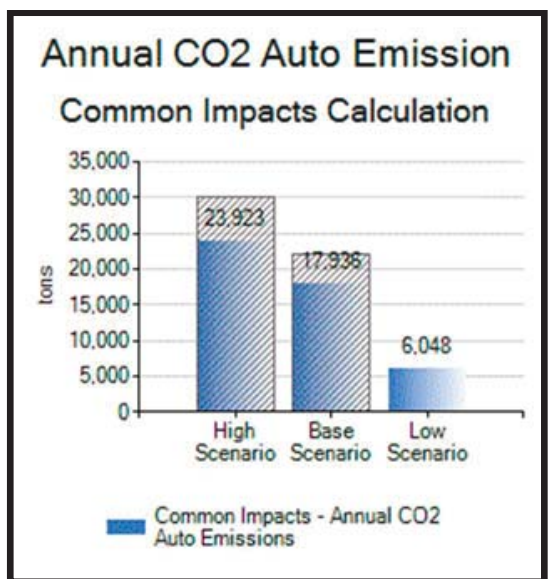

Fig. 17. 2016 CO2 Auto Emissions

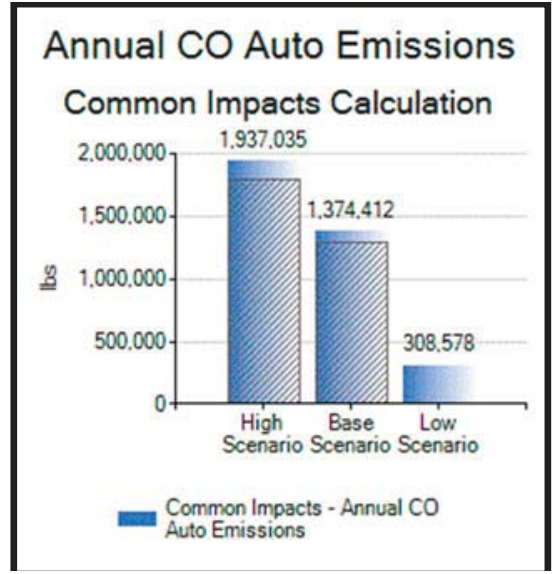

Fig.3. 2050 CO Auto Emissions

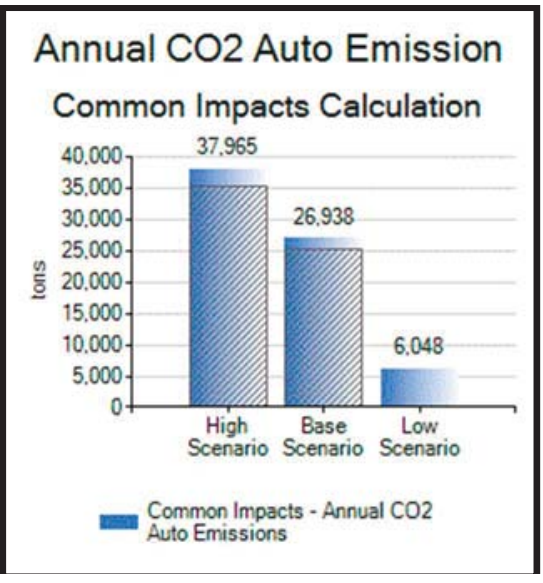

Fig. 18. 2050 CO2 Auto Emissions 


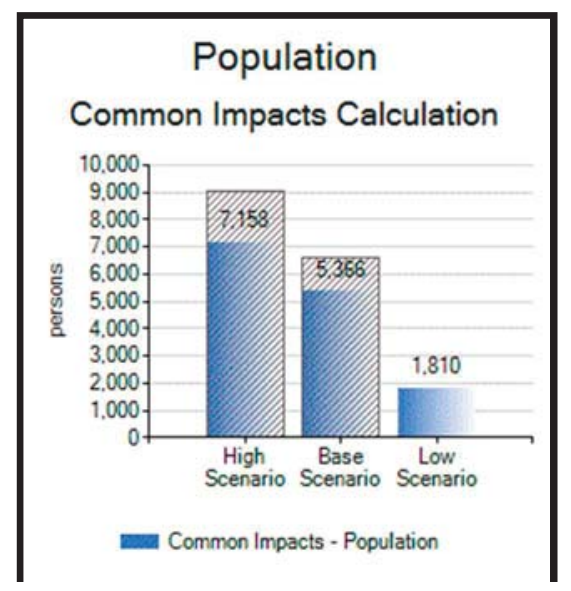

Fig. 19. 2016 Population Increase

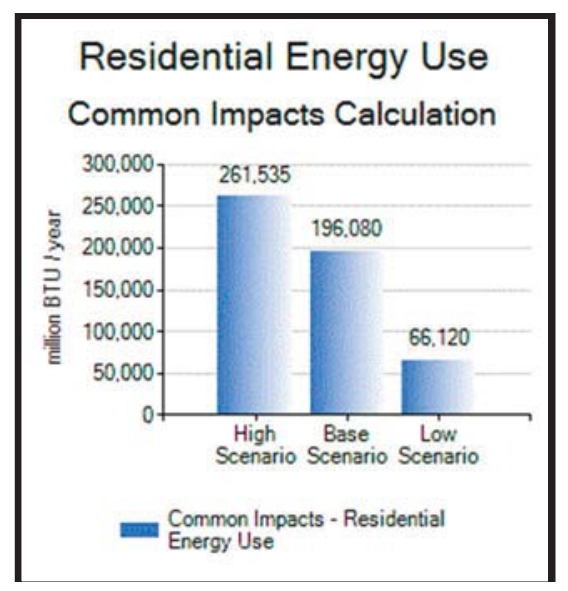

Fig.4. 2016 Residential Energy Usage

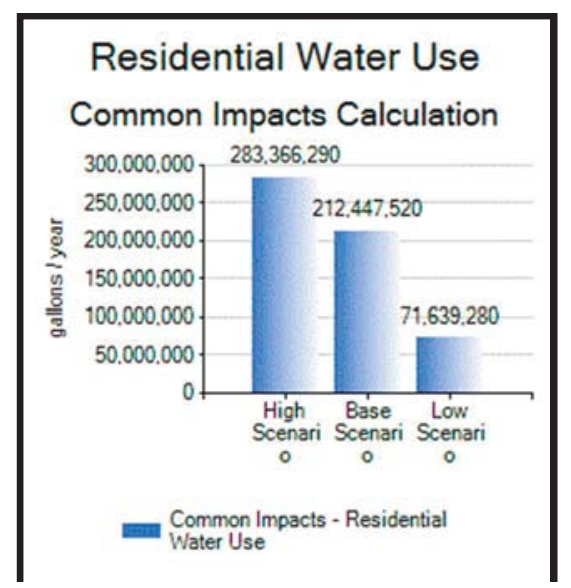

Fig. 23. 2016 Residential Water Usage

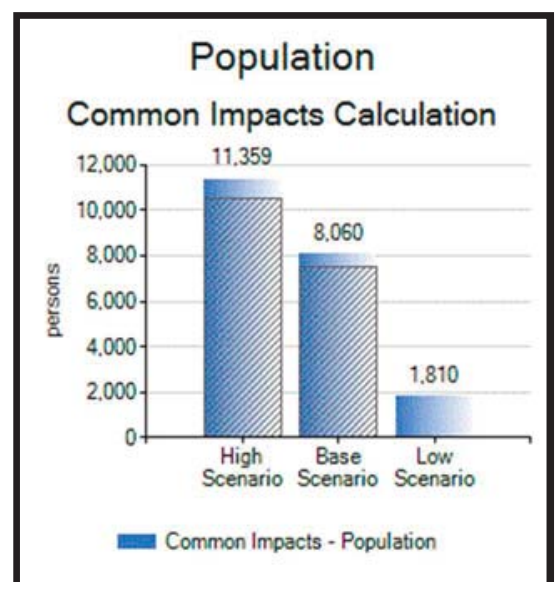

Fig. 20. 2050 Population Increase

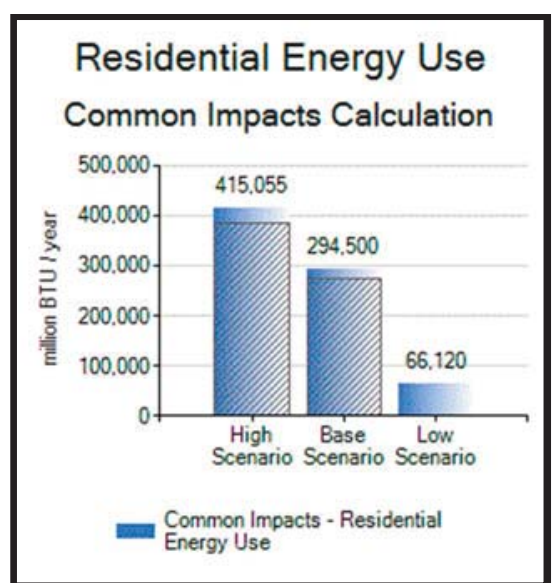

Fig. 5. 2050 Residential Energy Usage

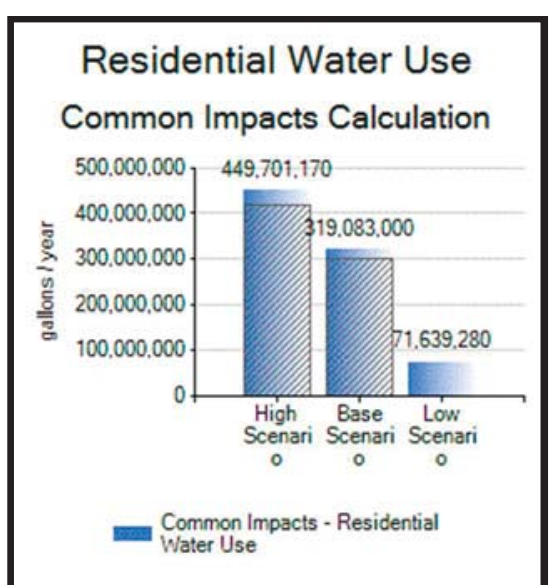

Fig. 24. 2050 Residential Water UsageSource: (Herron 2012) 


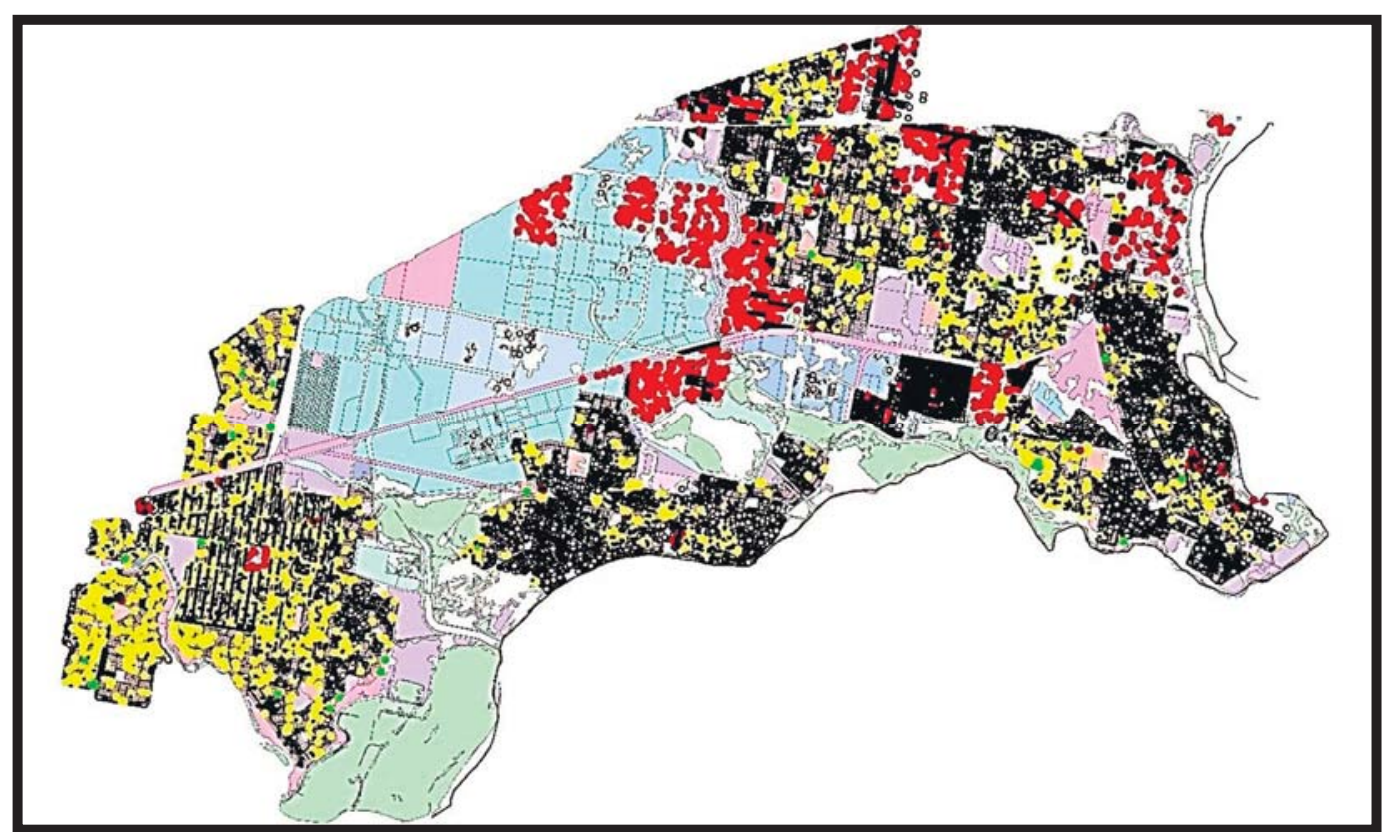

Fig. 25. City of Hobsons Bay Development 2050. Source:(Victorian Department of Primary Industry 2013)

Hobsons Bay Results. Every indicator showed substantial increase the result of increased population or development pressures. Figures 15 through 24 are sample simulated results for 2016 and 2050.

The research undertaken for this paper relating to the Hobsons Bay has generated eight discussion points which are listed below that can be summarized as: Population increases generating more emissions and greater impacts of climate change; Increased consumption of energy and water resources; Open space allowances decrease for new developments and General overall open space decreases per head of population; Urban density increases; For metropolitan areas (i.e. Hobsons Bay the scale of development) will increase; New residential and or commercial development will add greater stress on existing physical and or natural infrastructure; The exodus of more jobs (i.e. commercial and industrial jobs to peripheral areas and being replaced service industry jobs); and, More mixed commercial / residential developments in the metropolitan and regional centers. The detail of these 8 conclusions are detailed in table 4.

As indicated above, Hobsons Bay faces the impacts of climate change and sea level rise, as well as various other impacts due to population growth and human activities. It is now accepted and reflected in various literature, as well as in government policies internationally, and in Australia that concern is warranted to address the potential impacts of climate change in regional coastal areas.

Three Growth Scenarios for Hobsons Bay 2016-2050

Table 2

\begin{tabular}{|l|l|}
\hline 1 & $\begin{array}{l}\text { Population increases generating more emissions and greater Climate Change impacts. As the project } \\
\text { population increases the environmental indicators used to highlight environmental degradation in- } \\
\text { creased (i.e. } \mathrm{CO}, \mathrm{CO}^{2} \text {, Auto Emissions, residential water and energy consumption, etc.) The level of } \\
\text { increase is predicated on the number of cars and individuals per household. The more individuals or } \\
\text { cars per household the greater level of emission or consumption of water and energy per household. } \\
\text { In the Hobson Bay there is the possibility to reduce car numbers per household. This reduction is } \\
\text { the results of mass public transport which is located in the metropolitan region. }\end{array}$ \\
\hline 2 & $\begin{array}{l}\text { Water and energy consumption will increase as the result of population growth. The level of in- } \\
\text { crease can be reduced through water sensitive design and energy efficient equipment and applianc- } \\
\text { es. The other point on increased energy consumption is the substitution of coal based generated } \\
\text { electricity with electricity generated by renewable sources will reduce the impacts of climate } \\
\text { change on the landscape. }\end{array}$ \\
\hline 3 & $\begin{array}{l}\text { Open space ratio will decrease as a result new developments. The analysis show for communities } \\
\text { that had prescribed city or township boundaries new development or increased development will } \\
\text { reduce the allotted opens space per head of population. For HB the advent of high rise develop- } \\
\text { ments has reduced and will further reduce the open space ratio for residents as well developments } \\
\text { come on line. }\end{array}$ \\
\hline 4 & $\begin{array}{l}\text { Urban density increases. The current population for HB is } 90,000 \text { with an urban density of } 1,385 \\
\text { persons per ha by } 2050 \text { the population will be } 125,000 \text { with an estimated 1,922 per ha. }\end{array}$ \\
\hline
\end{tabular}




\begin{tabular}{|l|l|}
\hline 5 & $\begin{array}{l}\text { The scale of development in HB will increase. HB has only a limited area to incorporate the addi- } \\
\text { tional 25,000 to 30,000 residents by } 2050 \text { density and the scale of development will need to expand. } \\
\text { HB has just passed new building regulations and zoning regulations in } 2014 \text { that allow for the con- } \\
\text { struction of taller residential buildings (i.e. up } 30 \text { stories). Future regulations will increase the story } \\
\text { limit to 50 stories. }\end{array}$ \\
\hline 6 & $\begin{array}{l}\text { New residential and or commercial development will add greater stress on existing physical and or } \\
\text { natural infrastructure. HB will experience residential growth rate of. The residential growth levels } \\
\text { for the period } 2016 \text { through } 2050 \text { range from } 35 \text { to } 50 \% \text {. This growth will put stress on the natural } \\
\text { infrastructure such as beaches, marshes and coast lines. The future residential development will } \\
\text { require additional reticulated water and sewer systems. In the regional and rural study sites are ser- } \\
\text { viced by a combination of septic sewer systems and reticulated. }\end{array}$ \\
\hline 7 & $\begin{array}{l}\text { The exodus of commercial and industrial jobs to peripheral Greenfield sites away from the city } \\
\text { Centre. In HB industrial jobs are now being located in peripheral areas surrounding the respective } \\
\text { locations as industrial land which is close to the city centers is being rezoned for residential purpos- } \\
\text { es. The demand for residential land is such that current land uses are transformed into current and } \\
\text { future residential areas. }\end{array}$ \\
\hline 8 & $\begin{array}{l}\text { More mixed commercial / residential developments in the metropolitan and regional centers. The } \\
\text { addition of the mixed use zone into the Victorian planning system allows for greater flexibility for } \\
\text { mixed developments that contain both residential and commercial components. The four research } \\
\text { locations each have had their planning legislation augmented to incorporate the new planning zone. } \\
\text { Developers can obtain greater return through the use of mixed residential and commercial develop- } \\
\text { ment. }\end{array}$ \\
\hline
\end{tabular}

Conclusion and Outlook. The Apollo Bay and Hobsons Bay analyses comprised significant numbers of data sets, interdependencies, analyses, scenarios and outcomes. The topic of land use planning in Australia is both complex and multifaceted. The research question specifically asked could visualization techniques portray the information so that it is easily understood and thus more likely to be used. Over 150 datasets, 100 assumptions, 100 attributes and 100 indicators were used in the spatial analyses of the Apollo Bay and Hobsons Bay sites. Through the process of visualization what type of development would occur, where it would occur, when it would occur and the impact that development would have on the landscape and the environment, were evaluated.

The end product was a series of maps and charts that simply explained the proposed residential and commercial development of Apollo Bay and Hobson Bay and its associated impacts till 2050.

\section{REFERENCES}

1. Ciegis, R. (2009). 'The concept of Sustainable Development and its Use for Sustainability Scenarios.' Engineering Economics 2: pp. 28-37.

2. Herron, M. (2012). Looking for Sanity in Coastal Planning Deliberations. Geelong, Deakin Ph.D.

3. Victorian Department of Planning and Community Development (2014). 'VIF2014_ Victoria components of change.' from www.dpcd.vic.gov.au.

4. Victorian Department of Primary Industry (2013). Victoria GIS Data. Victorian Department of Primary Industry. Melbourne. ners Press

5. Walker, D. (2011). CommunityViz the essential tool fora new generation of planning. Chicago, Plan-

6. World Commission onEnvironment and Development (WCED) (1987). OurFuture. Oxford. 